\title{
Rosiglitazone attenuates the age-related changes in astrocytosis and the deficit in LTP
}

\author{
Thelma R. Cowley ${ }^{\mathrm{a}, *}$, Joan O’Sullivan ${ }^{\mathrm{a}}$, Christoph Blau ${ }^{\mathrm{a}}$, Brian F. Deighan ${ }^{\mathrm{a}}$, Raasay Jones ${ }^{\mathrm{a}}$, \\ Christian Kerskens ${ }^{\mathrm{a}}$, Jill C. Richardson ${ }^{\mathrm{b}}$, David Virley ${ }^{\mathrm{b}}$, Neil Upton ${ }^{\mathrm{b}}$, Marina A. Lynch ${ }^{\mathrm{a}}$ \\ ${ }^{a}$ Trinity College Institute of Neuroscience and Physiology Department, Trinity College, Dublin 2, Ireland \\ ${ }^{\mathrm{b}}$ Neuroscience Centre of Excellence for Drug Discovery, GlaxoSmithKline, Harlow, UK
}

\begin{abstract}
Neuroinflammation is a significant and consistent feature of many neurodegenerative disorders, including Alzheimer's disease (AD) and Parkinson's disease (PD). The greatest risk factor for neurodegenerative disorders is age and a proinflammatory phenotype in the aged brain is believed to contribute to these neurodegenerative conditions. In animal models, neuroinflammatory changes, characterized by increased microglial activation, have been associated with a loss of synaptic plasticity and here we show that treatment of aged rats with the PPAR $\gamma$ agonist, rosiglitazone, modulates the inflammatory changes and restores synaptic function. The evidence presented highlights an important role for astrocytes in inducing inflammatory changes and suggests that the age-related astrogliosis and astrocytosis is responsible for the increase in the proinflammatory cytokine, tumor necrosis factor alpha (TNF- $\alpha$ ). Magnetic resonance (MR) imaging revealed an age-related increase in $\mathrm{T} 1$ relaxation time and, importantly, treatment of aged rats with rosiglitazone reversed the age-related increases in astrogliosis and astrocytosis, TNF- $\alpha$ concentration and T1 relaxation time. The evidence indicates that the site of action for rosiglitazone is endothelial cells, and suggests that its effect on astrocytes is secondary to its effect on endothelial cells.
\end{abstract}

(C) 2010 Elsevier Inc. All rights reserved.

Keywords: Astrocytes; Hippocampus; Inflammation; Microglia; TNF- $\alpha$

\section{Introduction}

Several age-related changes in the hippocampus accompany the widely reported deficit in long-term potentiation (LTP); these include synapse loss, altered calcium homeostatic mechanisms, changes in receptor numbers and responsiveness (Rosenzweig and Barnes, 2003), changes in neurotrophins, their receptors and neurotrophin-induced signaling (Gooney et al., 2004; Rex et al., 2006) as well as changes in membrane composition which affects fluidity and therefore, potentially, the function of membrane-associated proteins (Yehuda et al., 2002). In addition, oxidative stress exerts a negative impact on LTP (Lynch, 2004) and a link between deficits in LTP and neuroinflammatory stress has also been reported with an inverse relationship established between hippocampal concentration of IL-1 $\beta$ and

\footnotetext{
* Corresponding author: Tel.: +3531 8968477; fax: +35316793545 E-mail address: tcowley@tcd.ie (T. Cowley).
}

LTP in aged, lipopolysaccharide (LPS)-treated and amyloid beta $(\mathrm{A} \beta$ )-treated rats (Lonergan et al., 2002; Lonergan et al., 2004; Lynch et al., 2007; Minogue et al., 2007). Thus predictably, IL-1 $\beta$ inhibits LTP in vitro and in vivo (Curran et al., 2003; Murray and Lynch, 1998) and $\mathrm{H}_{2} \mathrm{O}_{2}$ has also been shown to exert a similar detrimental effect, at least at low concentrations in young animals (Kamsler and Segal, 2003; Vereker et al., 2001). An inhibitory effect of TNF- $\alpha$ on LTP has also been reported (Butler et al., 2004; Cumiskey et al., 2007; Tancredi et al., 1992) and it has been identified as a key mediator in the inhibitory effect of $A \beta$ on LTP (Rowan et al., 2007). Recent evidence has indicated that when inflammatory and oxidative stress are inhibited by overexpression of mitochondrial transcription factor $\mathrm{A}$ (TFAM), the age-related decrease in LTP in CA1 is ameliorated (Hayashi et al., 2008), while eicosapentaenoic acid, which exerts anti-inflammatory and antioxidative effects similarly restores LTP in aged rats (Lynch et al., 2007; Martin et al., 2002). 
The age-related increased hippocampal concentration of IL- $1 \beta$ is accompanied by an increase in microglial activation providing circumstantial evidence of a causal relationship between these measures and supporting the view that activated microglia are the primary source of IL- $1 \beta$, as well as other proinflammatory cytokines (Block et al., 2007; Garden and Moller, 2006). Consistent with this is the finding that treatments like eicosapentaenoic acid and the lipid lowering compound, atorvastatin, which attenuate the agerelated increases in microglial activation and IL- $1 \beta$ concentration, lead to restoration of LTP (Clarke et al., 2008; Lynch et al., 2007). Recent evidence indicates that rosiglitazone, which attenuated the age-related increase in IL- $1 \beta$, was also associated with increased ability of aged rats to sustain LTP (Loane et al., 2009). However rosiglitazone did not inhibit the agerelated increase in MHCII mRNA suggesting that it did not affect microglial activation and that its effect on IL- $1 \beta$ was a consequence of an effect on another cell type.

The role of the astrocyte has traditionally been associated with its ability to provide metabolic support, to contribute to the maintenance of the blood brain barrier (BBB) and to underpin homeostasis ensuring appropriate ionic balance across cell membranes and maintenance of appropriate extracellular concentrations of transmitters, especially glutamate (Maragakis and Rothstein, 2006). However there is a growing recognition that these cells are central to immune responses in the CNS with evidence of a significant change in their morphology and metabolism in response to stressors. An increase in the activation state of astrocytes, typified by hypertrophy and upregulation in expression of the antigen glial fibrillary acidic protein (GFAP) and cell surface proteins like neural cell adhesion molecule (NCAM), accompanies microglial activation in conditions which are characterized by neurodegenerative changes; these include $\mathrm{AD}$, Huntington's disease, $\mathrm{PD}$, amyotrophic lateral sclerosis and cerebral ischemia (Maragakis and Rothstein, 2006). Evidence of proliferation of astrocytes with the morphological changes associated with activation has also been reported with age (Cotrina and Nedergaard, 2002; Maragakis and Rothstein, 2006). Although microglia are traditionally viewed as the most likely source of proinflammatory cytokines (Block et al., 2007; Garden and Moller, 2006), astrocytes also produce IL-1 $\beta$, IL- 6 and TNF- $\alpha$ in response to stressors (Lau and Yu, 2001; Yu and Lau, 2000). Here we considered that the modulatory effect of rosiglitazone on the age-related deficit in LTP might be a consequence of an effect on astrocytes, rather than microglia. We present evidence indicating that GFAP was markedly increased, at mRNA and protein levels, in the hippocampus of aged, compared with young, rats and show that these changes were coupled with increased $\mathrm{T} 1$ relaxation time and increased expression of RANTES which indicate astrocytic activation. Significantly rosiglitazone attenuated these agerelated changes and, in parallel, reduced the age-related increase in TNF- $\alpha$ and restored LTP. The data suggest that the action of rosiglitazone may be mediated by an interaction between endothelial cells and astrocytes.

\section{Methods}

\subsection{Animals}

Groups of young $(3 \mathrm{mo})$ and aged $(22 \mathrm{mo})$ male Wistar rats (Harlan, UK) were randomly assigned to control-treated and rosiglitazone-treated groups ( $\mathrm{n}=8$ per group). All rats were housed in groups of three and maintained under veterinary supervision in a controlled environment $(12 \mathrm{~h}$ light schedule; ambient temperature $22-23{ }^{\circ} \mathrm{C}$ ) and all experiments were performed under a license issued by the Department of Health (Ireland) and in accordance with the guidelines laid down by the local ethical committee. Animals had free access to food (standard laboratory chow; Red Mills, Ireland) and water and body weights were recorded throughout the study. Rosiglitazone maleate ( $3 \mathrm{mg} / \mathrm{rat}$ ) was administered daily in maple syrup $(0.2 \mathrm{~mL})$ for $56 \mathrm{~d}$, while rats in the control groups received only maple syrup; each animal was given their daily oral dose individually by allowing them to suck the maple syrup containing the rosiglitazone from a 1 $\mathrm{mL}$ syringe. Previous experiments had established that treatment with rosiglitazone for this period attenuated the agerelated decrease in LTP (Loane et al., 2009).

\subsection{MRI analysis}

On Day 54 of treatment, rats were anesthetized with isofluorane (4\% induction, 1.5-2\% maintenance; Abbot Laboratories, Ltd, UK) in $100 \%$ oxygen and secured in a custom-built cradle with ear bars to support the head. Respiration rate and temperature were monitored using purpose-built MRI-compatible monitoring equipment (SA Instruments, Stony Brook, NY). Temperature was maintained at $37.0-38.0^{\circ} \mathrm{C}$ using a feedback-controlled water-circulating heating system. Experiments were conducted on a seven Tesla BioSpec animal scanner (Bruker BioSpin, Ettlingen, Germany) equipped with a $20 \mathrm{~cm}$ actively-shielded gradient system and actively decoupled transmit $(12 \mathrm{~cm}$ Helmholtz) and receive ( $3 \mathrm{~cm}$ surface) coils. Gradient-echo pilot scans were used to ensure the animal was correctly positioned in the magnet, with the hippocampal region of interest (typically centered at $3.10 \mathrm{~mm}$ posterior to bregma) in the isocenter of the magnet to minimize imaging artefacts. For relaxometry studies, coronal images were obtained using a fast imaging with steady-state precession (FISP) protocol (Schmitt et al., 2004) under the following conditions: TE 1.5 $\mathrm{ms}$, TR $3.0 \mathrm{~ms}, 180^{\circ}$ phase advance, matrix $128 \times 128$, resolution $0.23 \times 0.23 \times 1.6 \mathrm{~mm}$, acquisition time 5 minute. From this, T1 and T2 maps were generated using an in-built macro in ParaVision software (Bruker, Germany). Regions of interest (hippocampus, cortex, thalamus and whole brain) were manually selected from a high-resolution scan of the same slice, and average values of regions in left and right hemispheres were used to determine $\mathrm{T} 1$ and $\mathrm{T} 2$ values in every 
region for each animal. Following imaging, animals were allowed to recover for $48 \mathrm{~h}$ before LTP was assessed.

\subsection{Induction of long-term potentiation in vivo}

On Day 56 of treatment, $24 \mathrm{~h}$ after the last dose of rosiglitazone, rats were anesthetized by intraperitoneal injection of urethane, $1.5 \mathrm{~g} \mathrm{~kg}^{-1}$. When necessary, a top-up dose of urethane, to a maximum of $2.5 \mathrm{~g} / \mathrm{kg}$, was given to achieve deep anesthesia indicated by the absence of a pedal reflex. The ability of rats to sustain LTP in perforant pathgranule cell synapses, in response to tetanic stimulation of the perforant path was assessed as previously described (Loane et al., 2009). At the end of the experiment, rats were killed by cervical dislocation, trunk blood was collected and plasma was prepared by adding $0.5 \mathrm{M}$ EDTA/5 M NaOH (5 $\mu \mathrm{L} / \mathrm{mL}$ ) and centrifugation at $10,000 \times \mathrm{g}$ for $10 \mathrm{~min}$ at $4{ }^{\circ} \mathrm{C}$. Samples were stored at $-80{ }^{\circ} \mathrm{C}$ for later analysis.

The brains were rapidly removed and hemisected. One portion of the brain was stored in Tissue Tek ${ }^{\circledR}$ OCT (Sakura Finetek, Europe) at $-80{ }^{\circ} \mathrm{C}$ and used for preparation of cryostat sections and subsequent immunohistochemical analysis of GFAP and OX-6 (Lynch et al., 2007). A second portion of brain tissue was used for preparation of dissociated cells and analysis by flow cytometry. The hippocampus and cortex were dissected from the remaining brain tissue and part of the hippocampus was placed in RNAlater (Ambion, UK) to ensure that the integrity of the RNA was maintained for later gene expression analysis. Tissue prisms $(350 \times 350 \mu \mathrm{m})$ were prepared from the remaining hippocampus and cortex and stored in Krebs buffer containing $10 \%$ dimethyl sulfoxide (DMSO) at $-80{ }^{\circ} \mathrm{C}$.

In a separate experiment, young rats were injected intracerebroventricularly $(4.1 \mathrm{~mm}$ lateral to bregma at a depth of $3.7 \mathrm{~mm}$ ) with TNF- $\alpha$ (40 ng in $5 \mu \mathrm{L}$; R\&D Systems Europe Ltd, UK) or vehicle, sterile PBS $(5 \mu \mathrm{L})$ over $10 \mathrm{~min}$, $2 \mathrm{~h}$ later, LTP was assessed as described above.

\subsection{Flow cytometric analysis}

Freshly dissected cortical and hippocampal tissue was cross-chopped and enzymatically digested in $5 \mathrm{~mL}$ Krebs buffer containing $10 \%$ collagenase D and $1 \%$ DNase, in a humidified incubator at $37{ }^{\circ} \mathrm{C}, 95 \%$ air and $5 \% \mathrm{CO}_{2}$ for 30 $\mathrm{min}$. Tissue was flushed through a $70-\mu \mathrm{m}$ cell strainer using Dulbecco's modified Eagle's medium (DMEM; Gibco®, Invitrogen, Ireland) supplemented with $10 \%$ fetal calf serum (FCS) and 1\% penicillin/streptomycin (Invitrogen, Ireland). The resultant single cell suspension was pelleted by centrifugation $(300 \times \mathrm{g}, 5 \mathrm{~min}$, room temperature $)$ and resuspended and incubated for $30 \mathrm{~min}$ in $5 \mathrm{~mL}$ complete DMEM containing $0.5 \mathrm{M}$ sucrose and $10 \% \mathrm{w} / \mathrm{v}$ peg- 1,000 (Fluka, UK). Samples were centrifuged at $300 \times \mathrm{g}$ for $5 \mathrm{~min}$ at $4{ }^{\circ} \mathrm{C}$ and resuspended in flow cytometry (FC) buffer (PBS $\left(137 \mathrm{mM} \mathrm{NaCl}, 8.1 \mathrm{mM} \mathrm{Na}{ }_{2} \mathrm{HPO}_{4}, 1.5 \mathrm{mM} \mathrm{KH}{ }_{2} \mathrm{PO}_{4}, 2.7\right.$ $\mathrm{mM} \mathrm{KCl} ; \mathrm{pH} 7.4$ ) containing $2 \% \mathrm{FCS}$ and $0.1 \%$ sodium azide). Cell suspensions were washed in this manner three times to remove DMEM.

Cell suspensions were blocked in FC buffer containing $50 \%$ FCS for $15 \mathrm{~min}$ at $4{ }^{\circ} \mathrm{C}$, washed as before to remove FC buffer, and stained with mouse anti-rat CD11b-Alexa Fluor 647 (Serotec, UK) and mouse anti-rat OX6-PerCP (BD Pharmingen, UK) for $30 \mathrm{~min}$ at $4{ }^{\circ} \mathrm{C}$ in the dark. Cell suspensions were washed and the number of $\mathrm{CD} 11 \mathrm{~b}$-positive cells expressing MHC II was analyzed using a DakoCytomation CyAn flow cytometer and FlowJo software.

\subsection{Preparation of cultured mixed glia and astrocytes}

Mixed glial and purified astrocyte cultures were prepared from the cortices of $1 \mathrm{~d}$ old Wistar rats, (BioResources Unit, Trinity College, Dublin, Ireland), as previously described (Nolan et al., 2005) and maintained in DMEM containing fetal bovine serum (FBS), penicillin, $100 \mathrm{U} \mathrm{mL}^{-1}$ and streptomycin, $100 \mathrm{U} \mathrm{mL}^{-1}$. Cells were grown at $37^{\circ} \mathrm{C}$ in a humidified $5 \% \mathrm{CO}_{2}: 95 \%$ air environment and media was changed every $3 \mathrm{~d}$. Dissected tissue was roughly chopped and added to prewarmed DMEM. Tissue was triturated, the suspension was filtered through a sterile mesh filter $(40 \mu \mathrm{m})$, centrifuged $\left(900 \times \mathrm{g}, 3 \mathrm{~min}, 20^{\circ} \mathrm{C}\right)$ and the pellet resuspended in warmed DMEM. For mixed glial cultures, cells were plated in 24-well plates at a density of $2.5 \times 10^{5}$ cells and incubated for $2 \mathrm{~h}$ before addition of warmed DMEM. We have established that these mixed glial cultures contain approximately $30 \%$ microglia and $70 \%$ astrocytes by flow cytometry.

Cells were grown in $25-\mathrm{cm}^{2}$ flasks in DMEM as above for the preparation of purified astrocyte cultures. After $12 \mathrm{~d}$ the flasks were shaken for $4 \mathrm{~h}$ at $110 \mathrm{rpm}$ at room temperature then tapped to remove non-astrocytic cells, the media was removed, the flasks were washed with sterile PBS and $1 \mathrm{~mL}$ of $0.05 \% \mathrm{w} / \mathrm{v}$ trypsin-EDTA was added at $37{ }^{\circ} \mathrm{C}$ until the cells just began to detach. DMEM was added to the flask to inhibit the trypsin, the cells were spun down at $900 \times \mathrm{g}$ for $3 \mathrm{~min}$, the pellet was resuspended in DMEM and cells were plated in six well plates at a density of $0.5 \times 10^{5}$ cells $/ \mathrm{mL}$. Flow cytometric analysis revealed that less that $10 \%$ of the cells in these cultures were $\mathrm{CD} 11 \mathrm{~b}^{-}$positive.

\subsection{Purification of astrocytes by MACS}

Magnetic-activated Cell Sorting (MACS; Miltenyi Biotec, GmbH, Germany) was used to deplete cultures of CD11b-positive cells. Purified astrocytes were prepared as described above and, after shaking and tapping, the cells were trypsinized and counted. The cells were washed with MACS buffer (PBS, 0.5\% BSA and $2 \mathrm{mM}$ EDTA) and centrifuged at $300 \times \mathrm{g}$ for $10 \mathrm{~min}$. The cells were resuspended in $100 \mu \mathrm{L}$ MACS buffer per $1 \times 10^{6}$ cells and labeled with mouse anti-rat CD11b-PE $(1: 200$, Abcam Plc, UK) in the dark for $30 \mathrm{~min}$ at $4{ }^{\circ} \mathrm{C}$. The cells were washed by adding $2 \mathrm{~mL}$ MACS buffer and centrifuging at $300 \times \mathrm{g}$ for $10 \mathrm{~min}$. Buffer was aspirated, $80 \mu \mathrm{L}$ MACS buffer and $20 \mu \mathrm{L}$ anti-PE microbeads (Miltenyi Biotec, GmbH, Ger- 
many) were added and the pellets were resuspended and incubated in the dark at $4{ }^{\circ} \mathrm{C}$ for $15 \mathrm{~min}$. The cells were washed as before and resuspended in $500 \mu \mathrm{L}$ MACS buffer. The CD11b-positive cells were depleted from the mixed population by the AutoMACS machine (Miltenyi Biotec, $\mathrm{GmbH}$, Germany) and CD11b-negative cells were collected and plated at $0.5 \times 10^{6}$ cells $/ \mathrm{mL}$ in DMEM. The cells were cultured for $4 \mathrm{~d}$ until confluent then a dose response to LPS was performed $(0-20 \mu \mathrm{g} / \mathrm{mL}$ LPS $)$ over $24 \mathrm{~h}$ and the supernatants tested for release of TNF- $\alpha$. Flow cytometric analysis revealed that less than $0.5 \%$ of the cells in these cultures were CD11b-positive.

\subsection{Treatment of mixed glial cultures}

Fourteen days after preparation, the mixed glial cells were incubated in the presence of rosiglitazone, $20 \mu \mathrm{M}$ for $24 \mathrm{~h}$ after which time LPS $(1 \mu \mathrm{g} / \mathrm{mL}$; Sigma, UK) or medium was added. Incubation continued for a further $24 \mathrm{~h}$. The supernatant was removed and stored at $-80{ }^{\circ} \mathrm{C}$ for analysis of cytokine concentration, and the cells were harvested in RA1 lysis buffer (Macherey-Nagel, Inc., Germany) for assessment of mRNA expression.

\subsection{Preparation of cultured endothelial cells}

The mouse brain endothelial cell line, bEnd.3 (ATCC, LGC Standards, UK), was cultured in DMEM containing FBS, penicillin and streptomycin in $25-\mathrm{cm}^{2}$ flasks until $90 \%$ confluent. The medium was removed and cells were rinsed in PBS to remove all traces of serum. Trypsin $(0.25 \% \mathrm{w} / \mathrm{v})$-EDTA $(0.03 \% \mathrm{w} / \mathrm{v})$ solution $(1-2 \mathrm{~mL}$; Gibcoß, Invitrogen, Ireland) was added and incubation continued at $37{ }^{\circ} \mathrm{C}$ until the cell layer began to detach. Complete growth medium $(6 \mathrm{~mL})$ was added and samples were centrifuged at $900 \times \mathrm{g}$ for $3 \mathrm{~min}$. The cell pellet was resuspended in complete DMEM and subcultured at a ratio of $1: 10$.

\subsection{Astrocyte-endothelia coculture}

Purified astrocytes were incubated in the presence of LPS (100 ng/mL) for $24 \mathrm{~h}$ and the endothelial cells (at $90 \%$ confluency) were treated with rosiglitazone, $20 \mu \mathrm{M}$ or vehicle $(0.04 \%$ DMSO) for $24 \mathrm{~h}$. The endothelial cells were trypsinized as described above and the pellet was resuspended in DMEM to provide a cell density of $0.5 \times 10^{5}$ cell $/ \mathrm{mL}$. The media was removed from the astrocytes, endothelial cell suspension $(1 \mathrm{~mL})$ was added and incubation continued for $24 \mathrm{~h}$. Supernatant was removed and stored for later analysis and the cells were harvested as described above for the mixed glia.

\subsection{Analysis of TNF- $\alpha$}

TNF- $\alpha$ was assessed in supernatant from cultured cells and in homogenate prepared from brain tissue using enzyme-linked immunosorbent assay (BD Biosciences, UK). Antibody-coated plates were incubated overnight at room temperature. The plates were washed three times with wash buffer (0.05\% Tween 20 in PBS, pH 7.4), blocking buffer (10\% FBS in PBS) was added and incubated for $1 \mathrm{~h}$ at room temperature. Plates were washed three times with wash buffer and standards $(0-2,000 \mathrm{pg} / \mathrm{mL}$ TNF- $\alpha)$ or samples $(100 \mu \mathrm{L})$ in duplicate were added to wells and incubated for $2 \mathrm{~h}$. Plates were washed three times; detection antibody in blocking buffer was added and incubated for a further 2 hour at room temperature. Plates were washed, incubated in horseradish peroxidase-conjugated streptavidin (1:200 dilution in blocking buffer) for $20 \mathrm{~min}$ at room temperature in the dark and washed again. TMB (Sigma-Aldrich, Ireland Ltd.) was added and samples were incubated in the dark at room temperature for 30 min. The reaction was stopped using $1 \mathrm{~N} \mathrm{H}_{2} \mathrm{SO}_{4}$, absorbance was read at $450 \mathrm{~nm}$ and values were expressed as $\mathrm{pg} / \mathrm{mL}$ or $\mathrm{pg} / \mathrm{mg}$ protein in the case of homogenates.

\subsection{1. mRNA analysis (CD11b, CD68, CD40R, iNOS, MHCII, GFAP, RANTES, IP-10 and TNF- $\alpha$ )}

RNA was extracted from hippocampal tissue and harvested cultured cells using a NucleoSpin RNAII isolation kit (Macherey-Nagel, Inc., Germany) according to the manufacturer's instructions. RNA concentrations were equalized to $1 \mu \mathrm{g}$ before cDNA synthesis using a High Capacity cDNA RT Kit (Applied Biosystems, UK) according to the manufacturer's instructions. Equal concentrations of cDNA were used for RT-PCR amplification. Real-time PCR primers were delivered as "Taqman ${ }^{\circledR}$ Gene Expression Assays" containing forward and reverse primers, and a FAM-labeled MGB TaqMan probe for each gene (Applied Biosystems, UK) as described previously (Downer et al., 2010). The assay IDs for the genes examined were as follows: CD11b (Rn00709342m1), CD68 (Rn01495631-m1), CD40R (Rn01423583-m1), GFAP (Rn00566603-m1), iNOS (Rn00561646-m1), IP-10 (Rn00594648-m1), MHC II (Rn01768597-m1), RANTES (Rn00579590-m1) and TNF- $\alpha$ (Rn99999017-m1). Gene expression was calculated relative to the endogenous control samples ( $\beta$-actin) to give a relative quantification (RQ) value ( $2^{-\mathrm{DDCT}}$, where CT is threshold cycle). We have compared $\beta$-actin in cDNA-equalized samples prepared from aged and young rats and have consistently found no age-related change.

\subsection{Fluorescent staining of GFAP and MHCII}

Cryostat sections $(10 \mu \mathrm{m})$ were prepared and assessed for GFAP and MHCII immunoreactivity as previously described (Lyons et al., 2007). Briefly, sections for the detection of GFAP were permeabilized with $0.1 \%$ Triton $\mathrm{X}-100^{\mathrm{TM}}$ (Sigma-Aldrich, Ireland Ltc.) in PHEM buffer (60-mM PIPES, $25 \mathrm{mM}$ HEPES, $10 \mathrm{mM}$ EGTA, $2 \mathrm{mM}$ $\mathrm{MgCl}_{2}$; Sigma-Aldrich, Ireland Ltd.), washed with PHEM buffer, fixed in ice cold methanol, washed and blocked for $2 \mathrm{~h}$ at room temperature in $10 \%$ goats serum $/ 4 \%$ BSA in PHEM. The polyclonal rabbit anti-GFAP $(1: 1,500$; Dako Diagnostics, Ireland) or mouse monoclonal MHCII antibody (OX6) (1 : 100; Serotec, UK) (or normal IgG antibodies as a negative control) were prepared in blocking buffer and incubated over- 
night at $4{ }^{\circ} \mathrm{C}$. Sections were washed and incubated with $\mathrm{Al}-$ exa488 secondary antibody (1 : 4,000 goat anti-rabbit or goat anti-mouse $\operatorname{IgG}$ as appropriate; Invitrogen) washed and mounted (Vectashield $®$ with Dapi, Vector Laboratories). Sections were viewed with a Zeiss 510 Meta confocal laser microscope at $\times 40$ magnification. DAPI staining of nuclei was visualized using the $543 \mathrm{~nm}$ helium neon laser.

\subsection{Statistical analysis}

Data were analyzed using either Student's $t$-test for independent means or a one-way analysis of variance (ANOVA) followed by post hoc Student-Newman-Keuls test to determine which conditions were significantly different from each other. Data are expressed as means with standard errors and deemed statistically significant when $p<0.05$.
In planning this study we used a-priori sample number calculations to determine the number of rats required to achieve statistical power of $80 \%$. Basing our calculation on our previously published rosiglitazone study (Loane et al., 2009), $\mathrm{n}=8$ was determined sufficient.

\section{Results}

\subsection{Rosiglitazone attenuated the increase in $T 1$ relaxation time in hippocampus of aged rats}

Analysis of $\mathrm{T} 1$ relaxation time revealed a significant age-related increase in the hippocampus $(* p<0.05$; ANOVA; aged vs. young controls; Fig. 1A) and rosiglitazone partially, but not significantly, attenuated this agerelated change so that there was no significant differences between values in young rats and aged rats treated with

A
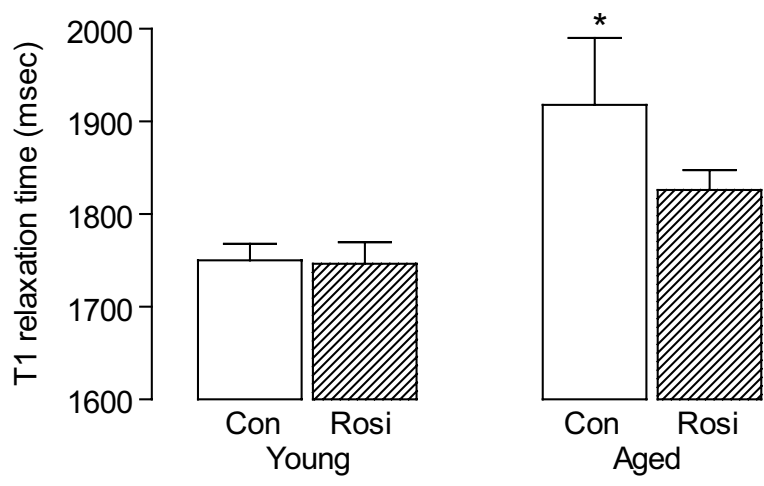

B

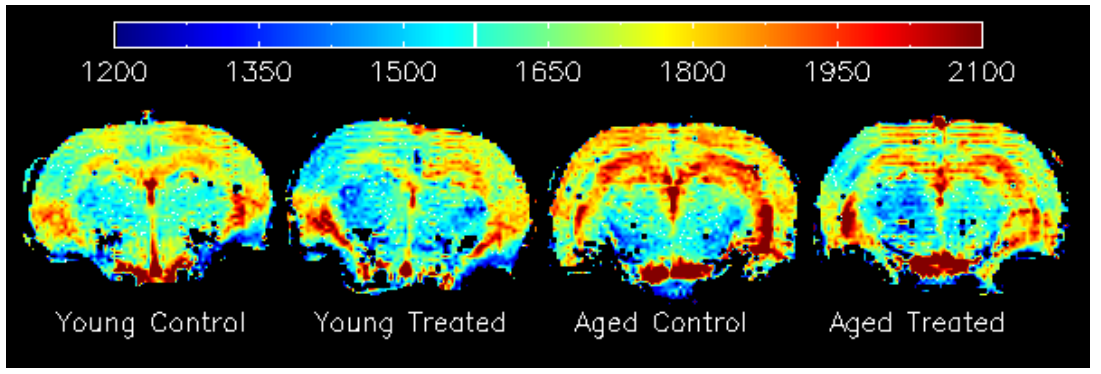

C
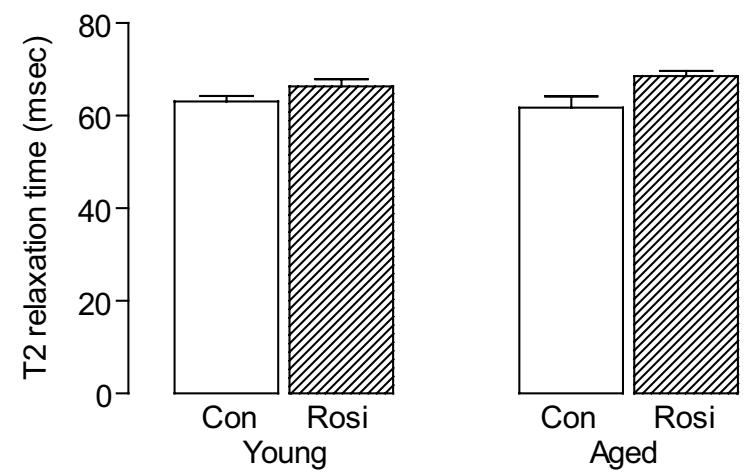

Fig. 1. (A, B) T1 relaxation time was significantly increased in the hippocampus of aged $(\mathrm{n}=5)$ compared with young $(\mathrm{n}=6)$, control-treated rats $(* p<$ 0.05 ; ANOVA); there is a partial attenuation of this age-related increase in T1 relaxation time by rosiglitazone in that there was no significant difference between young $(n=6)$, and aged $(n=5)$, rosiglitazone-treated rats. (C) T2 relaxation time was unaffected by age or treatment. 
rosiglitazone. Representative images confirm these age- and rosiglitazone-associated changes (Fig. 1B). T2 relaxation time was not significantly altered in hippocampus because of treatment with rosiglitazone or age (Fig. 1C).

\subsection{The age-related increase in microglial activation was not affected by rosiglitazone}

Expression of several markers of microglial activation were assessed in this study and the data indicate that expression of each of these was significantly increased in hippocampal tissue prepared from aged, compared with young, rats. Thus age-related increases were observed in mRNA expression of $\mathrm{CD} 11 \mathrm{~b}, \mathrm{CD} 68, \mathrm{CD} 40$ receptor (CD40R) and MHCII $(* p<0.05 ; * * p<0.01$; ANOVA; vs. young controls; Fig. 2A-D). Analysis of these markers in tissue prepared from aged, rosiglitazone-treated rats indicated that there was no statistically significant effect of treatment. Immunohistochemical analysis of OX6 staining also indicated an age-related increase (Fig. 2E; compare (i) and (iii)) and rosiglitazone did not markedly attenuate this effect. Flow cytometric analysis on cells prepared from aged and young, control- and rosiglitazone-treated rats confirmed
A. CD11b mRNA

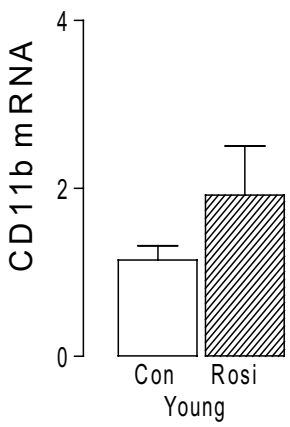

C. CD40R mRNA

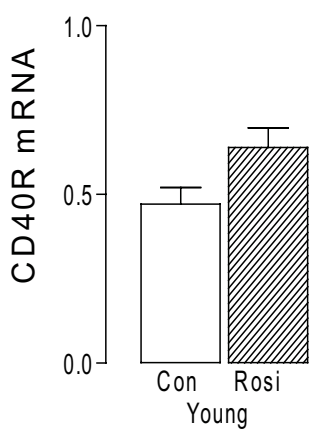

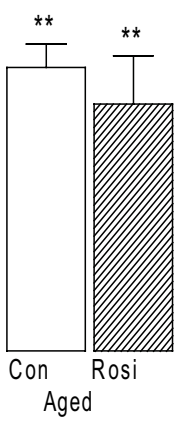

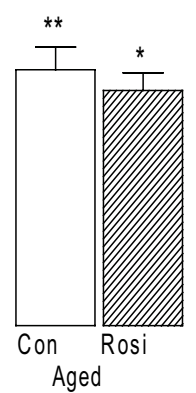

E. $0 \times 66^{+}$im munoreactivity

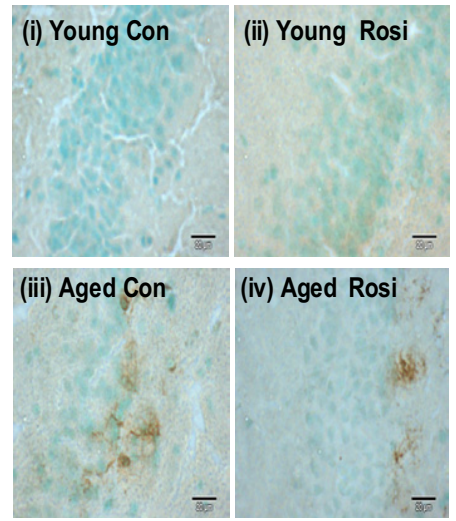

B. CD68 mRNA
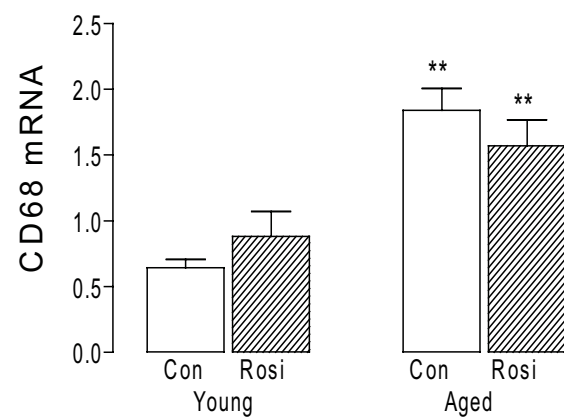

D. MHC II RNA
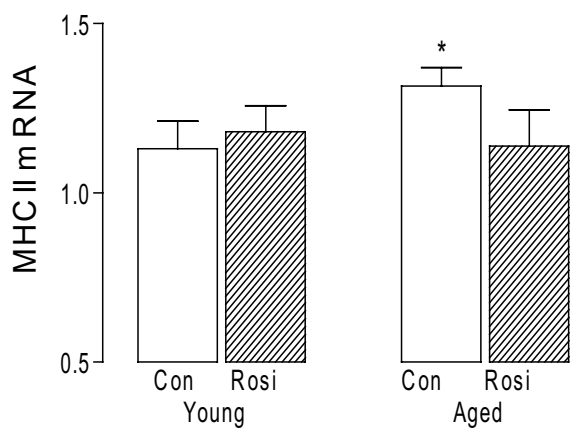

F. CD11b ${ }^{+} O \times 6^{+}$cells

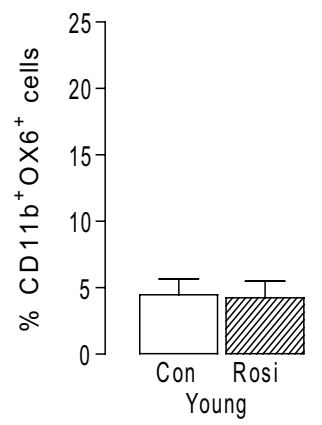

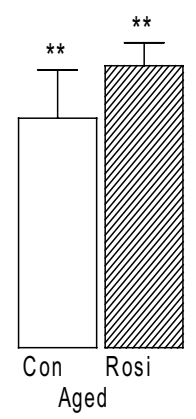

Fig. 2. Expression of CD11b (A), CD68 (B), CD40R (C) and MHCII (D) were significantly increased in hippocampal tissue prepared from aged, compared with young, rats $(* p<0.05 ; * * p<0.01$; ANOVA) and these changes persisted in hippocampal tissue prepared from aged, rosiglitazone-treated rats. (E) OX6 immunoreactivity was increased in sections prepared from hippocampus of aged, control-treated (iii) and rosiglitazone-treated (iv). (F) The number of CD11b ${ }^{+}$ $\mathrm{OX}^{+}$cells was significantly increased in tissue prepared from aged, control-treated and rosiglitazone-treated, compared with young, rats $(* * p<0.01 ;$ ANOVA) ( $\mathrm{n}=8$ in all groups). 
these findings and showed that the percentage of CD11b ${ }^{+}$, $\mathrm{OX}^{+}$cells was significantly increased in samples prepared from aged, compared with young, rats $(* * p<0.01$; ANOVA; vs. young controls; Fig. 2F). A similar increase was observed in samples prepared from aged rosiglitazonetreated rats $(* * p<0.01$; ANOVA; vs. young rosiglitazonetreated; Fig. 2F). On the basis of these analyses, we must conclude that rosiglitazone exerted no modulating effect on the age-related increase in microglial activation.

\subsection{Long-term potentiation in dentate gyrus was sustained in aged rats which received rosiglitazone}

Consistent with previous data, LTP, as assessed by a change in the population EPSP slope, was reduced in aged, compared with young, rats (Fig. 3A) and this effect was less marked in aged rats which received rosiglitazone (Fig. 3B). Analysis of the data in the last $10 \mathrm{~min}$ of the experiment revealed a significant decrease in mean population EPSP slope in aged, compared with young, rats $(* * * p<0.001$; ANOVA; vs. young controls; Fig. 3C) and a significant attenuation in rosiglitazone-treated aged rats $\left({ }^{+++} p<\right.$ 0.001; ANOVA; control-treated vs. rosiglitazone-treated aged rats).

\subsection{Rosiglitazone attenuated the age-related increase in astrocytosis}

Analysis of GFAP mRNA in hippocampal tissue prepared from these rats revealed an age-related increase $(* p<$ 0.05; ANOVA; vs. young controls; Fig. 4A) which was significantly attenuated in aged rats which received rosiglitazone $\left({ }^{+} p<0.05\right.$; ANOVA; control-treated vs. rosiglitazone-treated aged rats). GFAP immunoreactivity in hippocampus was also markedly enhanced in sections prepared from aged, compared with young, rats (Fig. 4B; compare (iii) with (i)); the age-related increase in GFAP immunoreactivity was clearly reduced in sections prepared from rosiglitazone-treated rats (compare (iv) with (iii)). This was confirmed by the data obtained from analysis of staining intensity, where the significant age-related increase ${ }^{*} p<$ 0.05; ANOVA; vs. young controls; Fig. 4C) was attenuated in aged rats treated with rosiglitazone $\left({ }^{+} p<0.05\right.$; ANOVA; control-treated vs. rosiglitazone-treated aged rats).

Activated astrocytes are a major source of chemokines including the chemoattractants, RANTES and IP-10 (Huang et al., 2000); here we show that the age-related increase in GFAP mRNA was coupled with increases in both chemokines. Figure 5A indicates that the age-related increase in RANTES mRNA in hippocampus ( $* * p<0.01$; ANOVA) was significantly inhibited in tissue prepared from aged rats which were treated with rosiglitazone $\left({ }^{+} p<0.05\right.$; ANOVA; control-treated vs. rosiglitazone-treated aged rats) and there was a significant correlation between expression of RANTES and GFAP ( $r=0.45, p<0.01$; Fig. 5B). IP-10 mRNA was also increased in hippocampal tissue prepared from aged rats $(* p<0.05$; ANOVA; vs. young controls;
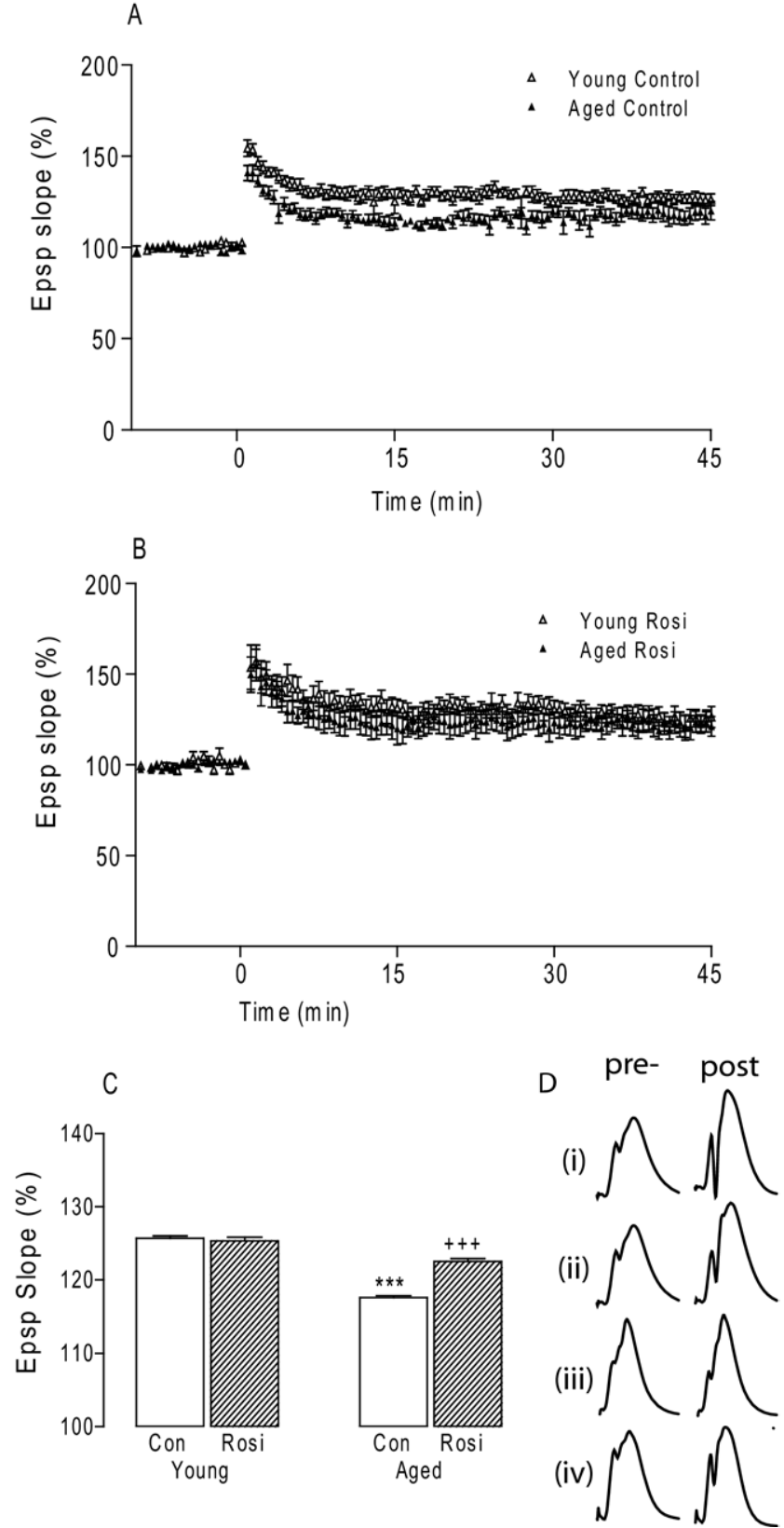

Fig. 3. (A) LTP in perforant path-granule cell synapses in urethaneanesthetized rats was reduced in aged control-treated rats compared with young control-treated rats but was similar in rosiglitazone-treated young and aged rats (B). (C) Analysis of population epsp slope in the last 10 minute of the experiment indicated that there was a significant age-related change $(* * * p<0.001$; ANOVA), which was attenuated in aged, rosiglitazone-treated rats $\left({ }^{++} p<0.001\right.$; ANOVA) ( $\mathrm{n}=8$ for all groups). (D) Line graphs show representative epsps pre-HFS and of the last 10 minute of recordings for (i) young control, (ii) young rosiglitazone-treated, (iii) aged control and (iv) aged rosiglitazone-treated.

Fig. 5C) and although this effect was attenuated in tissue prepared from aged rosiglitazone-treated rats, the attenuation did not reach statistical significance. A significant correlation between IP-10 mRNA and GFAP mRNA was also observed ( $r=0.57, p<0.001$; Fig. 5D). 


\section{A. GFAP mRNA}
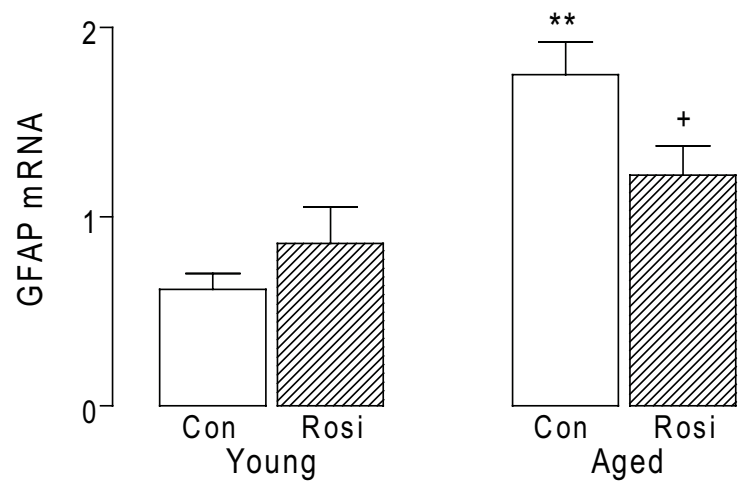

B. GFAP im m unoreactivity

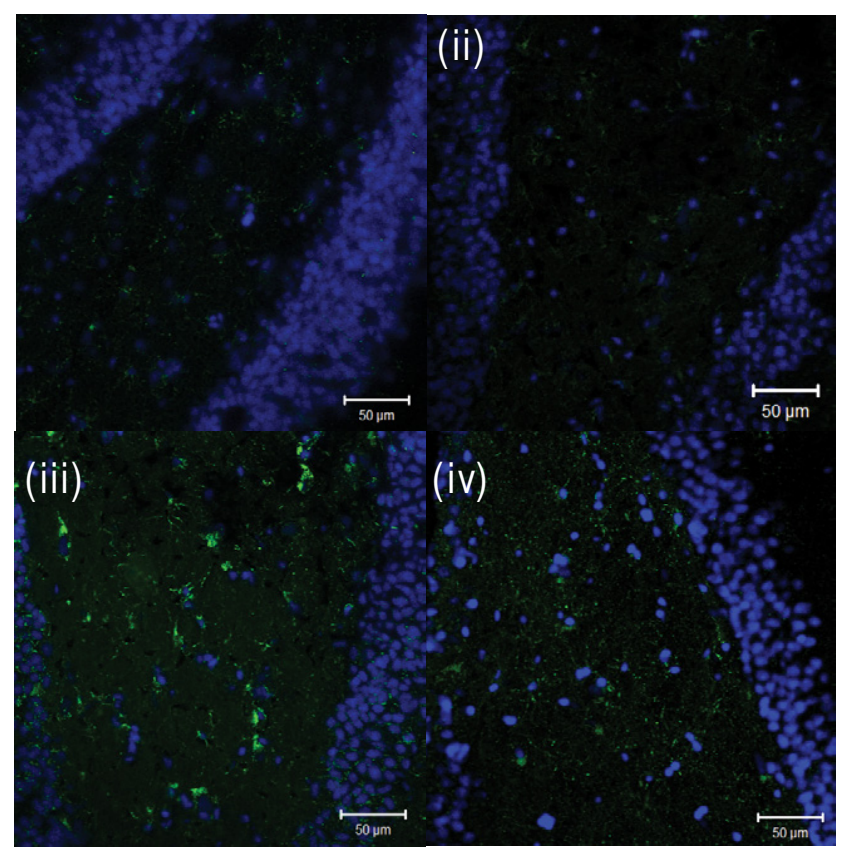

C. GFAP staining intensity

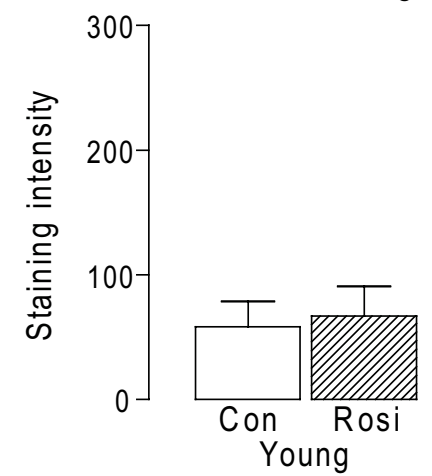

\subsection{Rosiglitazone decreased LPS-induced astrocyte activation in vitro}

Astrocytes secrete several cytokines, including TNF- $\alpha$, in response to inflammatory stimuli (Chung and Benveniste, 1990) and consistent with this, the age-related increases in markers of activated astrocytes described here, were accompanied by a significant increase in TNF- $\alpha$ mRNA $(* p<$ 0.05; ANOVA; vs. young controls; Fig. 6A) and protein $\left({ }^{*} p<0.05\right.$; ANOVA; vs. young controls; Fig. 6B). Rosiglitazone reduced both measures and this was significant in the case of TNF- $\alpha$ concentration $\left({ }^{++} p<0.01\right.$; ANOVA; control-treated vs. rosiglitazone-treated aged rats; Fig. 6B). In vitro analysis indicated that LPS significantly increased TNF- $\alpha$ mRNA and protein in purified astrocyte cultures $\left({ }^{* *} p<0.01 ; * * * p<0.001\right.$; ANOVA; Fig. $6 \mathrm{C}$ and D) and that rosiglitazone significantly attenuated the LPS-induced changes in protein $\left(^{+++} p<0.001\right.$; ANOVA; LPS-treated in the presence vs. the absence of rosiglitazone; Fig. 6D) but not mRNA (Fig. 6C). LPS similarly increased TNF- $\alpha$ in mixed glial cultures $(* * p<0.01$; ANOVA) but rosiglitazone exerted no effect in this case (Fig. 6E); this indicates that mixed glia and isolated cells do not always respond similarly to stimuli highlighting the fact that complex interactions between microglia and astrocytes occur (Shih et al., 2006).

These data suggest that TNF- $\alpha$ may play a key role in inducing the observed age-related changes, and because it has been shown to impair LTP in vitro (Butler et al., 2002; Cumiskey et al., 2007; Pickering et al., 2005; Stellwagen and Malenka, 2006; Tancredi et al., 1992) but not, to date in vivo, we assessed its effect on LTP in perforant path-granule cell synapses in urethane-anesthetized rats. The data show that it significantly reduced the ability of rats to sustain LTP $(p<0.001$; Fig. 6F).

\subsection{The interaction between endothelial cells and astrocytes is modulated by rosiglitazone}

Because rosiglitazone does not easily cross the BBB we considered that its effect on astrocytes might be a consequence of an interaction between endothelial cells and astrocytes and to address this, the modulatory effect of rosiglitazone-treated endothelial cells on LPS-induced release of TNF- $\alpha$ from purified astrocyte cultures was examined. TNF- $\alpha$ was significantly increased when LPS-treated astrocytes were cocultured in the presence of endothelial cells $(* * * p<0.001$; ANOVA; Fig. 7A). However if LPS-treated astrocytes were cocultured in the presence of endothelial

effect in young rats (ii), it reduced the GFAP immunoreactivity in sections prepared from aged rats (iv). (C) Analysis of fluorescent intensity revealed that there was a significant increase in preparations obtained from aged, compared with young, control-treated rats ( $* * p<0.01$; ANOVA); this was significantly attenuated in preparations obtained from aged, rosiglitazonetreated rats $\left({ }^{+} p<0.05\right.$; ANOVA).
Fig. 4. (A) GFAP mRNA was significantly increased in the hippocampus of aged, control-treated rats (** $p<0.01$; ANOVA); this was significantly attenuated in aged, rosiglitazone-treated rats $\left({ }^{+} p<0.05\right.$; ANOVA). (B) GFAP immunoreactivity was markedly increased in sections of hippocampus prepared from aged, control-treated (iii), compared with young, control-treated (i) rats and whereas rosiglitazone treatment exerted no marked 

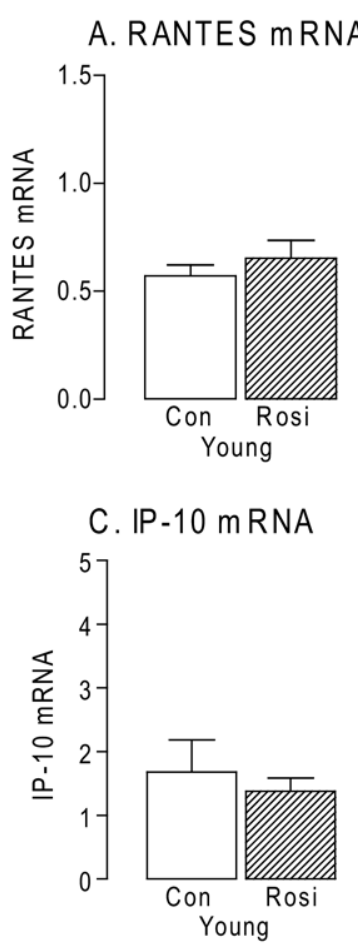
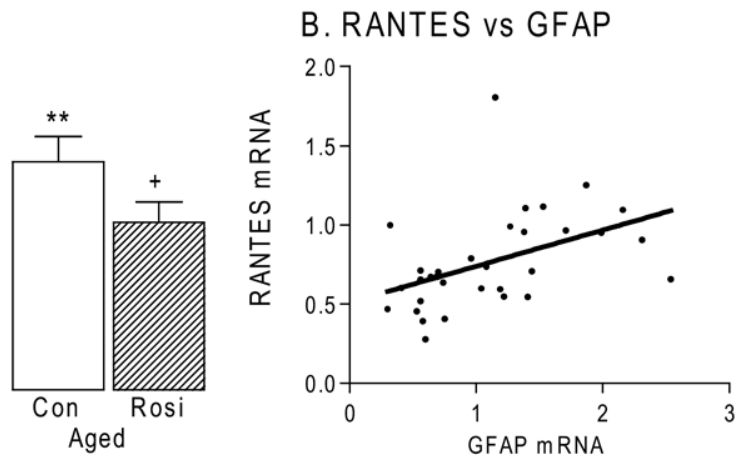

D. IP-10 vs GFAP
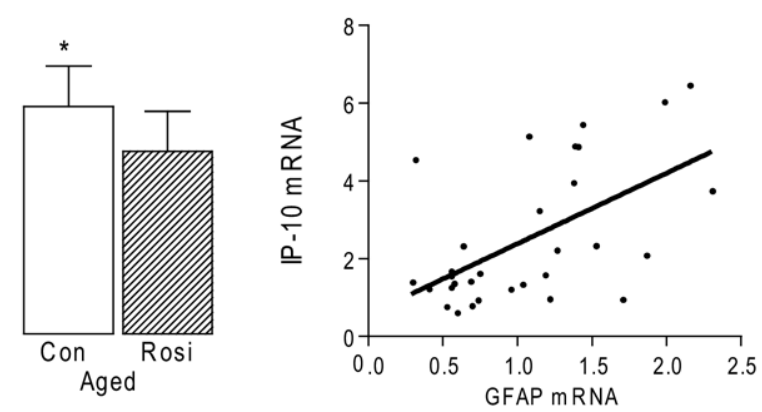

Fig. 5. RANTES (A) and IP-10 (C) mRNA were significantly increased in hippocampal tissue prepared from aged, compared with young, rats $(* p<0.05$; $* * p<0.01$; ANOVA); the age-related increase in RANTES mRNA was significantly attenuated in tissue prepared from rosiglitazone-treated aged rats $\left({ }^{+} p<0.05\right.$; ANOVA). Expression of RANTES $(r=0.45, p<0.01)$ (B) and IP-10 $(r=0.57, p<0.001)$ (D) significantly correlated with expression of GFAP ( $\mathrm{n}=8$ for all groups).

cells that were pretreated with rosiglitazone, then the increase in TNF- $\alpha$ was less marked and was significantly reduced compared with astrocytes which were cocultured with control endothelial cells $\left({ }^{++} p<0.01\right.$; ANOVA; Fig. 7A). These changes were paralleled by similar changes in RANTES mRNA; thus RANTES expression was significantly increased in LPS-treated astrocytes cocultured with control endothelial cells $(* * p<0.01$; ANOVA) and this effect was attenuated when astrocytes were coincubated with rosiglitazone-treated endothelial cell $\left({ }^{+} p<0.05\right.$; ANOVA; Fig. 7B). However RANTES mRNA was also significantly increased in control astrocytes cocultured with endothelia $\left({ }^{\S} \mathrm{p}<0.01\right.$; ANOVA) probably reflecting the fact that it is expressed by both astrocytes and endothelial cells (Sanders et al., 1998; Sorensen et al., 1999).

\subsection{Highly purified astrocytes release TNF- $\alpha$ in response to $L P S$}

To demonstrate that purified astrocytes release TNF- $\alpha$, CD11b-positive cells (i.e., microglia) were depleted by MACS, and assessed for their ability to release TNF- $\alpha$ in response to LPS; the data indicate that LPS significantly increased TNF- $\alpha$ in supernatant prepared from LPS-treated, compared with control-treated cells $(* * p<0.01$; ANOVA; Fig. 8A). Flow cytometric analysis revealed that, in this preparation, only $0.57 \%$ of the cells were CD11b-positive (Fig. 8B). As a positive control, mixed glial cultures were similarly analyzed and $8 \%$ of the cells were CD11b-positive (Fig. 8A); the red histogram shows astrocytes and the green shows mixed glia in which a shift to the right indicates positive staining for $\mathrm{CD} 11 \mathrm{~b}$.

\section{Discussion}

The objective of this study was to establish whether activation of astrocytes contributes to the neuroinflammatory changes and the decrease in synaptic plasticity which occurs in the aged rat and to assess the mechanism by which rosiglitazone attenuates these age-related changes. The data presented support the view that astrocytes play a key role in mediating the modulatory effects of rosiglitazone on LTP and suggest that the mechanism involves its ability to decrease TNF- $\alpha$ production. Given its limited ability to cross the BBB (Strum et al., 2007; unpublished data), we propose that rosiglitazone mediates its effect by an action on endothelial cells which interact with astrocytes (Abbott et al., 2006) to modulate TNF- $\alpha$ production.

Several cell surface markers were used to assess the modulatory effects of age and rosiglitazone on microglial activation and the combined data reveal consistent evidence of an age-related increase in microglial activation which was not affected by rosiglitazone. MHCII mRNA was increased in an age-related manner which was similar to that previously reported (Loane et al., 2009; Lynch et al., 2007). 
A. TNF $\alpha$ mRA

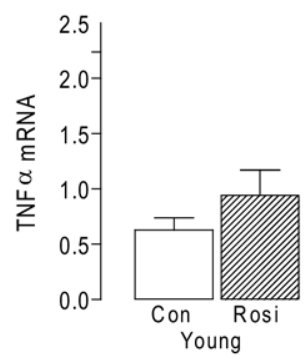

C. Astrocytes: TNF $\alpha$ mRNA
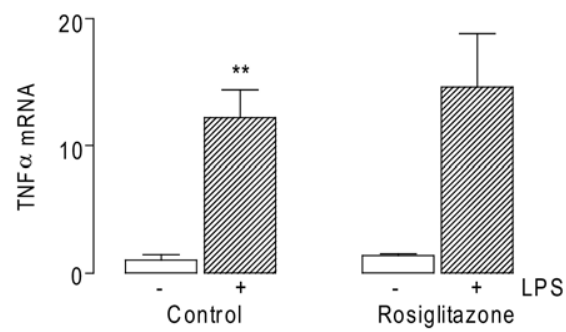

E. Mixed glia: $[T N F \alpha]$

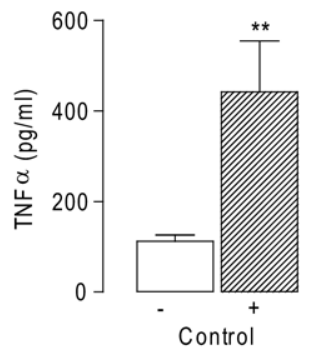

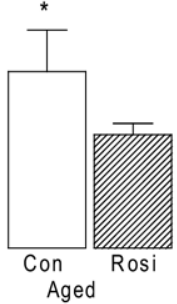

Aged

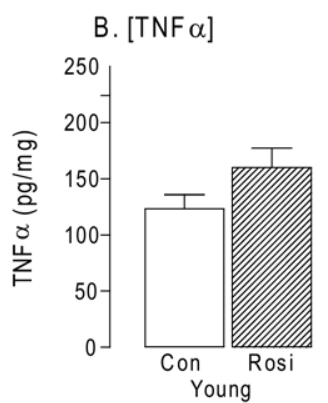

D. Astrocytes: $[\mathrm{TNF} \alpha]$

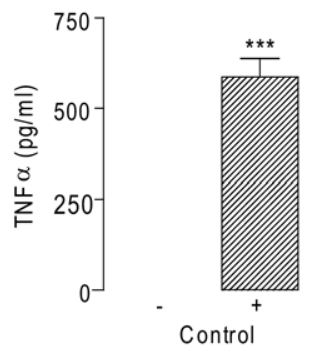

F. LTP

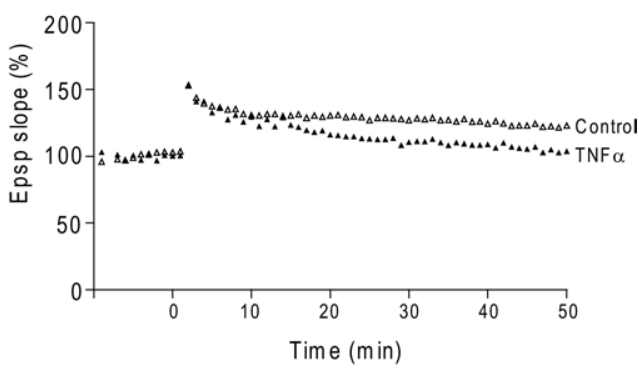

Fig. 6. TNF- $\alpha$ mRNA (A) and protein (B) were significantly increased in tissue prepared from aged $(\mathrm{n}=7)$, compared with young $(\mathrm{n}=8)$, rats $(* p<0.05$; ANOVA) and the change in TNF- $\alpha$ concentration was significantly attenuated in tissue prepared from aged rats which received rosiglitazone $(\mathrm{n}=8)\left({ }^{++} p<\right.$ 0.01 ; ANOVA). LPS significantly increased TNF- $\alpha$ mRNA (C) and protein (D) in cultured astrocytes $(* * p<0.01 ; * * *<0.001 ;$ ANOVA; $\mathrm{n}=5$ per group); pretreatment with rosiglitazone significantly attenuated the LPS-induced change in TNF- $\alpha$ concentration in supernatant $\left({ }^{+++} p<0.001 ;\right.$ ANOVA; $\mathrm{n}=4$ per group). (E) LPS significantly increased TNF- $\alpha$ concentration in supernatant obtained from mixed glia (** $p<0.01$; ANOVA; $\mathrm{n}=6$ per group) but this was unaffected by pretreatment with rosiglitazone ( $\mathrm{n}=6$ per group). (F) Intracerebroventicular injection of TNF- $\alpha$ markedly decreased LTP in perforant path-granule cells in urethane anesthetized rats $(n=2)$.

This was consolidated by analysis of dissociated cells by cell cytometry which revealed an age-related increase in cells expressing CD11b and MHCII, and by immunohistochemical analysis which demonstrated an age-related increase in OX6 (anti-MHCII) immunoreactivity. None of the age-related changes in these markers were affected by rosiglitazone. Similar age-related increases in CD68, CD11b and CD40R mRNA were identified. CD68 is a lysosomeassociated glycoprotein which is expressed specifically on phagocytic cells and which is upregulated by phagocytosis (da Silva and Gordon, 1999). The integrin, CD11b, is also commonly used as a marker of microglial activation; it is a binding protein for ICAM-1 and plays a role in chemotaxis and it also binds complement $\mathrm{C} 3 \mathrm{bi}$ and phagocytoses $\mathrm{C} 3 \mathrm{bi}-$ expressing particles (Zen et al., 2004). CD40R is a member of the TNFR superfamily and its interaction with the ligand CD40 plays a significant role in the immune response, controlling release of cytokines like TNF- $\alpha$. Like CD68 and $\mathrm{CD} 11 \mathrm{~b}$, its expression on microglia is upregulated upon cell activation (Nguyen et al., 1998). Like MHCII mRNA the age-related increases in expression of CD40R, CD11b and CD68 were unaffected by rosiglitazone treatment. We must conclude from this evidence that microglia are not a target cell for rosiglitazone at least in the context of modulating expression of cell surface markers (Loane et al., 2009).

Evidence of astrogliosis and astrocytosis was identifiable in sections of hippocampus obtained from aged rats. Further evidence of astrocytic activation was provided by the marked age-related increase in expression of GFAP mRNA in hippocampal tissue, and these findings concur with previous reports and with our findings that GFAP mRNA and GFAP immunoreactivity were also observed in cortical tissue prepared from aged rats (data not shown). Increased GFAP immunoreactivity was observed in hippocampus of 

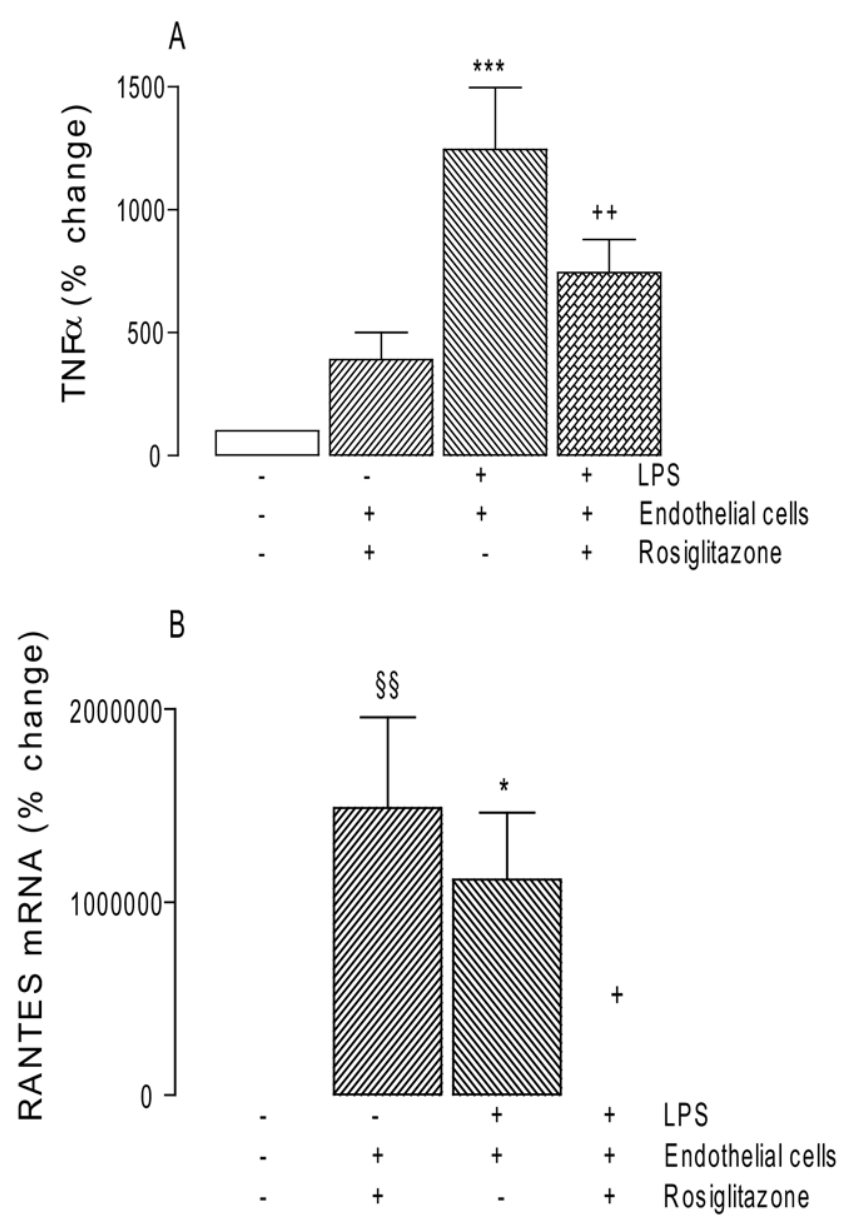

Fig. 7. TNF- $\alpha$ (A) and RANTES mRNA (B) were significantly increased when LPS-treated astrocytes were cocultured in the presence of endothelial cells $(* p<0.05 ; * * * p<0.001$; ANOVA; $\mathrm{n}=6$ per group) but this effect was attenuated when LPS-treated astrocytes were cocultured in the presence of endothelial cells that were pretreated with rosiglitazone $\left({ }^{+} p<\right.$ $0.05 ;{ }^{++} p<0.01$; ANOVA; $\mathrm{n}=6$ per group). RANTES mRNA was also significantly increased when astrocytes and endothelial cells were cocultured in the absence of LPS $\left({ }^{\S \S} p<0.01\right.$; ANOVA).

mice older than $50 \mathrm{w}$ (Hayakawa et al., 2007) and an age-related increase in GFAP mRNA and protein has also been reported in thalamus and hypothalamus as well as hippocampus (Goss et al., 1991; Kohama et al., 1995). One of the striking findings presented here is that treatment of aged rats with rosiglitazone inhibited GFAP immunoreactivity and GFAP mRNA indicating that rosiglitazone specifically targets astrocytes, contrasting with its lack of effect on microglia.

We report an age-related increase in the physical property of spin-lattice relaxation time (T1) in rat hippocampus which is attenuated by treatment with rosiglitazone. Increased $\mathrm{T} 1$ relaxation time, leading to hypointensity in $\mathrm{T} 1$ weighted images, has been used as a qualitative tool in MR image analysis by radiologists to determine severity and deterioration in conditions such as cerebral hemorrhage (Anzalone et al., 2004; Barkhof et al., 1998). The age- related and rosiglitazone-related changes in T1-relaxation time is mirrored by the changes in GFAP immunoreactivity suggesting a link between $\mathrm{T} 1$ and astrocytic activation, a finding that is in accord with work published by others (Sibson et al., 2008). In contrast, no change in T2 relaxation time in either the hippocampus (or the cortex; data not shown) was observed. This is consistent with other studies in this laboratory where no change in $\mathrm{T} 2$ relaxation time was observed in rats up to 18 mo of age (unpublished) and with the findings of a previous report showing no changes in T2 relaxation time in rats up to 12 mo of age (Heiland et al., 2002).

Astrocytes and endothelial cells are acknowledged sources of chemokines in the brain and both are a major source of RANTES (Sanders et al., 1998; Sorensen et al., 1999), which is a T cell, monocyte and eosinophil chemoattractant (Huang et al., 2000). Expression of RANTES in astrocytes and endothelial cells is stimulated by inflammatory cytokines like TNF- $\alpha$ (Croitoru-Lamoury et al., 2003; Hillyer et al., 2003). Conversely, RANTES can also increase the expression of TNF- $\alpha$ from astrocytes (Luo et al., 2002). Here we show that RANTES mRNA and TNF- $\alpha$ mRNA and protein were increased in hippocampal tissue
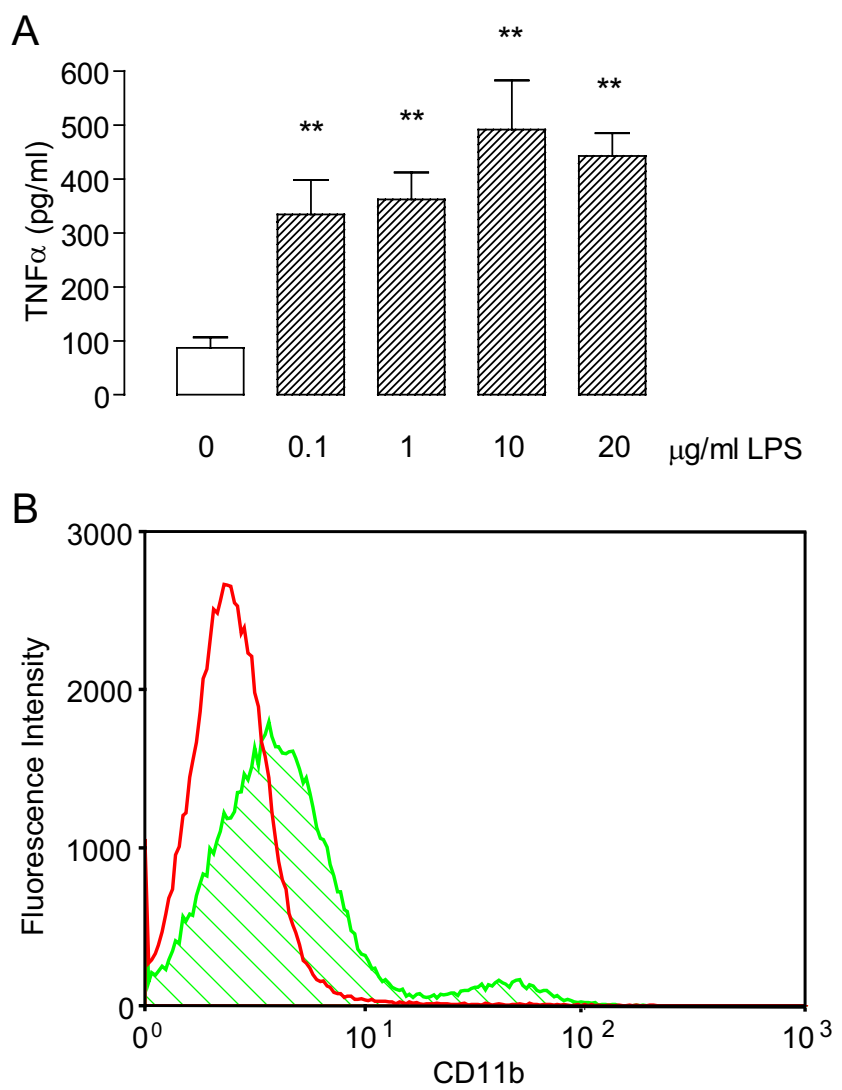

Fig. 8. (A) LPS significantly increased TNF- $\alpha$ release in purified astrocytes $(* * p<0.01$; ANOVA; $\mathrm{n}=6$ ). (B) Flow cytometric analysis revealed that the astrocytic culture was $99.43 \%$ pure; representative histograms of astrocytes (red) and mixed glia (green) indicated that $0.57 \%$ and $8 \%$ of the cells in the astrocyte and mixed glia cultures were CD11b-positive. 
prepared from aged, compared with young, rats in agreement with earlier findings (Felzien et al., 2001; Gavilan et al., 2007). This link between RANTES and TNF- $\alpha$ may represent a mechanism by which amplification of inflammatory processes occurs because, in addition to its upregulation in response to inflammatory cytokines, RANTES has been shown to induce expression of several cytokines and chemokines and this suggests it may initiate inflammatory cascades (Luo et al., 2003). It is possible therefore that RANTES may provide a molecular target by which inflammation could be limited; it is in this regard that it is noteworthy that GFAP mRNA expression, a marker of astrocyte activation, correlates with expression of RANTES.

Treatment with rosiglitazone markedly inhibited the agerelated increases in RANTES mRNA and this is consistent with the finding that the promoter region of the RANTES gene contains a PPAR $\gamma$ response element (Pritts et al., 2003) and the observation that PPAR $\gamma$ ligands modulate RANTES expression in human dendritic cells (Gosset et al., 2001). We have previously shown that rosiglitazone inhibits the age-related increase in IL- $1 \beta$ in hippocampus, although it exerted no effect on MHCII mRNA, suggesting that the source of IL-1 $\beta$ may not be microglia (Loane et al., 2009). The parallel age-related increases, and rosiglitazone-associated changes, in markers of astrocytic activation and in TNF- $\alpha$ mRNA and protein which are described here, provide evidence suggesting that these cells may be the source of TNF- $\alpha$. Astrocyte cultures which are $90-95 \%$ pure can release TNF- $\alpha$ as suggested by the present results, and by others (Giri et al., 2004; Storer et al., 2005), but it is acknowledged that microglial contamination may contribute to this. However we demonstrate here that MACS-purified astrocytes (99.5\% pure) also release TNF- $\alpha$. Although a similar effect of LPS on TNF- $\alpha$ was observed in mixed glia, the modulatory effect of rosiglitazone was confined to astrocytes providing further evidence that rosiglitazone affects astrocytic function.

It is well known that neuroinflammatory changes impact negatively on synaptic plasticity (Loane et al., 2009; Lynch et al., 2007; Minogue et al., 2007), and the present findings link the age-related decrease in LTP in dentate gyrus with astrocytic activation and increase in TNF- $\alpha$. Several groups have reported modulatory effects of TNF- $\alpha$ on synaptic plasticity. For instance, some groups have reported that TNF- $\alpha$ exerts an inhibitory effect on LTP in dentate gyrus and CA1 in vitro (Butler et al., 2004; Cumiskey et al., 2007; Tancredi et al., 1992) while others report no effect in CA1 (Stellwagen and Malenka, 2006). Interestingly although LTP was unaffected in TNF receptor-deficient mice, LTD could not be recorded in these animals (Albensi and Mattson, 2000). To our knowledge, this is the first report of a similar change in dentate gyrus in vivo; although TNF- $\alpha$ has been implicated as a factor which contributes to the inhibition of LTP induced by A $\beta$ in vivo (Rowan et al., 2007). As previously reported, the age-related decrease in LTP was attenuated in rats treated with rosiglitazone (Loane et al., 2009) and the evidence suggested that the effect was mediated by IL- 4 which is released from astrocytes (Deighan et al., 2008). The evidence presented here suggests that the activated astrocytes present in the brain of aged rats release TNF- $\alpha$ and thereby exert a negative impact on LTP, while rosiglitazone downregulates astrocyte activation and TNF- $\alpha$ production and consequently leads to restoration of LTP. It should be recognized that one mechanism by which inflammatory changes may influence LTP is by means of its negative impact on neurogenesis (Iosif et al., 2006; Monje et al., 2003), which is known to contribute to expression of LTP (Snyder et al., 2001) and to decline with age (Galvan and Jin, 2007) in parallel with the appearance of neuroinflammatory changes.

The ability of rosiglitazone to cross the BBB is limited (Strum et al., 2007), and therefore the mechanism by which it exerts its effect on astrocytes must be addressed. Interactions between endothelial cells and astrocytes at the BBB have been eloquently described in a recent review by Abbott and colleagues (Abbott et al., 2006). Here we describe an interaction between these cells, specifically showing that rosiglitazone-treated endothelial cells affects TNF- $\alpha$ release and RANTES mRNA expression. RANTES is expressed by both astrocytes and endothelial cells (Sanders et al., 1998; Sorensen et al., 1999) but we propose that the rosiglitazoneassociated changes are endothelial cell-dependent, because at least in this in vitro experiment, a direct effect of rosiglitazone on astrocytes could not occur. On the basis of these findings, we propose that the action of rosiglitazone in the CNS is not dependent on its ability to cross the BBB but that its primary effect is on endothelial cells and that its immunomodulatory and anti-inflammatory effects are a result of an interaction between endothelial cells and astrocytes. Because its ability to cross the BBB is limited, the finding that rosiglitazone interacts with endothelial cell, thereby modulating astrocyte function, may be an important factor in considering potential therapeutic uses.

\section{Disclosure statement}

Thelma Cowley, Joan O'Sullivan, Jill Richardson, David Virley and Neil Upton are employed by GlaxoSmithKline. Otherwise there are no conflicts of interest.

\section{Acknowledgements}

The first two authors contributed equally to this article. This work was supported by a grant from GlaxoSmithKline and the Industrial Development Agency Ireland. RJ and BD were supported by grants obtained from the Health Research Board (Ireland) [grant number HRB RP/2006/2012Lynch]. 


\section{References}

Abbott, N.J., Ronnback, L., Hansson, E., 2006. Astrocyte-endothelial interactions at the blood-brain barrier. Nat Rev Neurosci. 7(1), 41-53.

Albensi, B.C., Mattson, M.P., 2000. Evidence for the involvement of TNF and NF-kappaB in hippocampal synaptic plasticity. Synapse. 35(2), $151-159$.

Anzalone, N., Scotti, R., Riva, R., 2004. Neuroradiologic differential diagnosis of cerebral intraparenchymal hemorrhage. Neurol Sci. 25 Suppl 1, S3-5.

Barkhof, F., McGowan, J.C., van Waesberghe, J.H., Grossman, R.I., 1998. Hypointense multiple sclerosis lesions on T1-weighted spin echo magnetic resonance images: their contribution in understanding multiple sclerosis evolution. J Neurol Neurosurg Psychiatry. 64 Suppl 1, S77-79.

Block, M.L., Zecca, L., Hong, J.S., 2007. Microglia-mediated neurotoxicity: uncovering the molecular mechanisms. Nat Rev Neurosci. 8(1), 57-69.

Butler, M.P., Moynagh, P.N., O'Connor, J.J., 2002. Methods of detection of the transcription factor NF-kappa B in rat hippocampal slices. J Neurosci Methods. 119(2), 185-190.

Butler, M.P., O'Connor, J.J., Moynagh, P.N., 2004. Dissection of tumornecrosis factor-alpha inhibition of long-term potentiation (LTP) reveals a p38 mitogen-activated protein kinase-dependent mechanism which maps to early-but not late-phase LTP. Neuroscience. 124(2), 319-326.

Chung, I.Y., Benveniste, E.N., 1990. Tumor necrosis factor-alpha production by astrocytes. Induction by lipopolysaccharide, IFN-gamma, and IL-1 beta. J Immunol. 144(8), 2999-3007.

Clarke, R.M., Lyons, A., O'Connell, F., Deighan, B.F., Barry, C.E., Anyakoha, N.G., Nicolaou, A., Lynch, M.A., 2008. A pivotal role for interleukin-4 in atorvastatin-associated neuroprotection in rat brain J Biol Chem. 283(4), 1808-1817.

Cotrina, M.L., Nedergaard, M., 2002. Astrocytes in the aging brain. J Neurosci Res. 67(1), 1-10.

Croitoru-Lamoury, J., Guillemin, G.J., Boussin, F.D., Mognetti, B., Gigout, L.I., Cheret, A., Vaslin, B., Le Grand, R., Brew, B.J., Dormont, D., 2003. Expression of chemokines and their receptors in human and simian astrocytes: evidence for a central role of TNF alpha and IFN gamma in CXCR4 and CCR5 modulation. Glia. 41(4), 354-370.

Cumiskey, D., Butler, M.P., Moynagh, P.N., O'Connor, J.J., 2007. Evidence for a role for the group I metabotropic glutamate receptor in the inhibitory effect of tumor necrosis factor-alpha on long-term potentiation. Brain Res. 1136(1), 13-19.

Curran, B.P., Murray, H.J., O'Connor, J.J., 2003. A role for c-Jun Nterminal kinase in the inhibition of long-term potentiation by interleukin-1beta and long-term depression in the rat dentate gyrus in vitro. Neuroscience. 118(2), 347-357.

da Silva, R.P., Gordon, S., 1999. Phagocytosis stimulates alternative glycosylation of macrosialin (mouse CD68), a macrophage-specific endosomal protein. Biochem J. 338 (Pt 3), 687-694.

Deighan, B.F., Griffin, R., Loane, D.J., Lynch, M.A. Rosiglitazone attenuates the LPS-induced increase in IL-1b via IL-4 release from astrocytes. 9th International Congress of Neuroimmunology. Fort Worth, Texas, USA; 2008.

Downer, E.J., Cowley, T.R., Lyons, A., Mills, K.H., Berezin, V., Bock, E., Lynch, M.A., 2010. A novel anti-inflammatory role of NCAM-derived mimetic peptide, FGL. Neurobiol Aging. 31(1), 118-128.

Felzien, L.K., McDonald, J.T., Gleason, S.M., Berman, N.E., Klein, R.M., 2001. Increased chemokine gene expression during aging in the murine brain. Brain Res. 890(1), 137-146.

Galvan, V., Jin, K., 2007. Neurogenesis in the aging brain. Clin Interv Aging. 2(4), 605-610.

Garden, G.A., Moller, T., 2006. Microglia biology in health and disease. J Neuroimmune Pharmacol. 1(2), 127-137.

Gavilan, M.P., Revilla, E., Pintado, C., Castano, A., Vizuete, M.L., Moreno-Gonzalez, I., Baglietto-Vargas, D., Sanchez-Varo, R., Vitorica, J., Gutierrez, A., Ruano, D., 2007. Molecular and cellular characterization of the age-related neuroinflammatory processes occur- ring in normal rat hippocampus: potential relation with the loss of somatostatin GABAergic neurons. J Neurochem. 103(3), 984-996.

Giri, S., Rattan, R., Singh, A.K., Singh, I., 2004. The 15-deoxy-delta12,14prostaglandin $\mathrm{J} 2$ inhibits the inflammatory response in primary rat astrocytes via down-regulating multiple steps in phosphatidylinositol 3-kinase-Akt-NF-kappaB-p300 pathway independent of peroxisome proliferator-activated receptor gamma. J Immunol. 173(8), 5196-5208.

Gooney, M., Messaoudi, E., Maher, F.O., Bramham, C.R., Lynch, M.A., 2004. BDNF-induced LTP in dentate gyrus is impaired with age: analysis of changes in cell signaling events. Neurobiol Aging. 25(10), 1323-1331.

Goss, J.R., Finch, C.E., Morgan, D.G., 1991. Age-related changes in glial fibrillary acidic protein mRNA in the mouse brain. Neurobiol Aging. 12(2), 165-170.

Gosset, P., Charbonnier, A.S., Delerive, P., Fontaine, J., Staels, B., Pestel, J., Tonnel, A.B., Trottein, F., 2001. Peroxisome proliferator-activated receptor gamma activators affect the maturation of human monocytederived dendritic cells. Eur J Immunol. 31(10), 2857-2865

Hayakawa, N., Kato, H., Araki, T., 2007. Age-related changes of astorocytes, oligodendrocytes and microglia in the mouse hippocampal CA1 sector. Mech Ageing Dev. 128(4), 311-316.

Hayashi, Y., Yoshida, M., Yamato, M., Ide, T., Wu, Z., Ochi-Shindou, M., Kanki, T., Kang, D., Sunagawa, K., Tsutsui, H., Nakanishi, H., 2008. Reverse of age-dependent memory impairment and mitochondrial DNA damage in microglia by an overexpression of human mitochondrial transcription factor a in mice. J Neurosci. 28(34), 8624-8634.

Heiland, S., Sartor, K., Martin, E., Bardenheuer, H.J., Plaschke, K., 2002. In vivo monitoring of age-related changes in rat brain using quantitative diffusion magnetic resonance imaging and magnetic resonance relaxometry. Neurosci Lett. 334(3), 157-160.

Hillyer, P., Mordelet, E., Flynn, G., Male, D., 2003. Chemokines, chemokine receptors and adhesion molecules on different human endothelia: discriminating the tissue-specific functions that affect leucocyte migration. Clin Exp Immunol. 134(3), 431-441.

Huang, D., Han, Y., Rani, M.R., Glabinski, A., Trebst, C., Sorensen, T., Tani, M., Wang, J., Chien P., O’Bryan, S., Bielecki, B., Zhou, Z.L., Majumder, S., Ransohoff, R.M., 2000. Chemokines and chemokine receptors in inflammation of the nervous system: manifold roles and exquisite regulation. Immunol Rev. 177, 52-67.

Iosif, R.E., Ekdahl, C.T., Ahlenius, H., Pronk, C.J., Bonde, S., Kokaia, Z., Jacobsen, S.E., Lindvall, O., 2006. Tumor necrosis factor receptor 1 is a negative regulator of progenitor proliferation in adult hippocampal neurogenesis. J Neurosci. 26(38), 9703-9712.

Kamsler, A., Segal, M., 2003. Hydrogen peroxide modulation of synaptic plasticity. J Neurosci. 23(1), 269-276.

Kohama, S.G., Goss, J.R., Finch, C.E., McNeill, T.H., 1995. Increases of glial fibrillary acidic protein in the aging female mouse brain. Neurobiol Aging. 16(1), 59-67.

Lau, L.T., Yu, A.C., 2001. Astrocytes produce and release interleukin-1, interleukin-6, tumor necrosis factor alpha and interferon-gamma following traumatic and metabolic injury. J Neurotrauma. 18(3), 351-359.

Loane, D.J., Deighan, B.F., Clarke, R.M., Griffin, R.J., Lynch, A.M., Lynch, M.A., 2009. Interleukin-4 mediates the neuroprotective effects of rosiglitazone in the aged brain. Neurobiol Aging. 30(6), 920-931.

Lonergan, P.E., Martin, D.S., Horrobin, D.F., Lynch, M.A., 2002. Neuroprotective effect of eicosapentaenoic acid in hippocampus of rats exposed to gamma-irradiation. J Biol Chem. 277(23), 20804-20811.

Lonergan, P.E., Martin, D.S., Horrobin, D.F., Lynch, M.A., 2004. Neuroprotective actions of eicosapentaenoic acid on lipopolysaccharide-induced dysfunction in rat hippocampus. J Neurochem. 91(1), 20-29.

Luo, Y., Berman, M.A., Abromson-Leeman, S.R., Dorf, M.E., 2003. Tumor necrosis factor is required for RANTES-induced astrocyte monocyte chemoattractant protein-1 production. Glia. 43(2), 119-127.

Luo, Y., Berman, M.A., Zhai, Q., Fischer, F.R., Abromson-Leeman, S.R., Zhang, Y., Kuziel, W.A., Gerard, C., Dorf, M.E., 2002. RANTES 
stimulates inflammatory cascades and receptor modulation in murine astrocytes. Glia. 39(1), 19-30.

Lynch, A.M., Loane, D.J., Minogue, A.M., Clarke, R.M., Kilroy, D., Nally, R.E., Roche, O.J., O'Connell, F., Lynch, M.A., 2007. Eicosapentaenoic acid confers neuroprotection in the amyloid-beta challenged aged hippocampus. Neurobiol Aging. 28(6), 845-855.

Lynch, M.A., 2004. Long-term potentiation and memory. Physiol Rev. 84(1), 87-136.

Lyons, A., Downer, E.J., Crotty, S., Nolan, Y.M., Mills, K.H., Lynch, M.A., 2007. CD200 ligand receptor interaction modulates microglial activation in vivo and in vitro: a role for IL-4. J Neurosci. 27(31), 8309-8313.

Maragakis, N.J., Rothstein, J.D., 2006. Mechanisms of Disease: astrocytes in neurodegenerative disease. Nat Clin Pract Neurol. 2(12), 679-689.

Martin, D.S., Lonergan, P.E., Boland, B., Fogarty, M.P., Brady, M., Horrobin, D.F., Campbell, V.A., Lynch, M.A., 2002. Apoptotic changes in the aged brain are triggered by interleukin-1beta-induced activation of p38 and reversed by treatment with eicosapentaenoic acid. J Biol Chem. 277(37), 34239-34246.

Minogue, A.M., Lynch, A.M., Loane, D.J., Herron, C.E., Lynch, M.A., 2007. Modulation of amyloid-beta-induced and age-associated changes in rat hippocampus by eicosapentaenoic acid. J Neurochem. 103(3), 914-926.

Monje, M.L., Toda, H., Palmer, T.D., 2003. Inflammatory blockade restores adult hippocampal neurogenesis. Science. 302(5651), 17601765.

Murray, C.A., Lynch, M.A., 1998. Evidence that increased hippocampal expression of the cytokine interleukin-1 beta is a common trigger for age- and stress-induced impairments in long-term potentiation. J Neurosci. 18(8), 2974-2981.

Nguyen, V.T., Walker, W.S., Benveniste, E.N., 1998. Post-transcriptional inhibition of CD40 gene expression in microglia by transforming growth factor-beta. Eur J Immunol. 28(8), 2537-2548.

Nolan, Y., Maher, F.O., Martin, D.S., Clarke, R.M., Brady, M.T., Bolton, A.E., Mills, K.H., Lynch, M.A., 2005. Role of interleukin-4 in regulation of age-related inflammatory changes in the hippocampus. J Biol Chem. 280(10), 9354-9362.

Pickering, M., Cumiskey, D., O'Connor, J.J., 2005. Actions of TNF-alpha on glutamatergic synaptic transmission in the central nervous system. Exp Physiol. 90(5), 663-670.

Pritts, E.A., Zhao, D., Sohn, S.H., Chao, V.A., Waite L.L., Taylor R.N., 2003. Peroxisome proliferator-activated receptor-gamma ligand inhibition of RANTES production by human endometriotic stromal cells is mediated through an upstream promoter element. Fertil Steril. 80(2), 415-420.

Rex, C.S., Lauterborn, J.C., Lin, C.Y., Kramar, E.A., Rogers, G.A., Gall, C.M., Lynch, G., 2006. Restoration of long-term potentiation in middle-aged hippocampus after induction of brain-derived neurotrophic factor. J Neurophysiol. 96(2), 677-685.

Rosenzweig, E.S., Barnes, C.A., 2003. Impact of aging on hippocampal function: plasticity, network dynamics, and cognition. Prog Neurobiol. 69(3), 143-179.
Rowan, M.J., Klyubin, I., Wang, Q., Hu, N.W., Anwyl, R., 2007. Synaptic memory mechanisms: Alzheimer's disease amyloid beta-peptide-induced dysfunction. Biochem Soc Trans. 35(Pt 5), 1219-1223.

Sanders, V.J., Pittman, C.A., White, M.G., Wang, G., Wiley, C.A., Achim, C.L., 1998. Chemokines and receptors in HIV encephalitis. AIDS. 12(9), 1021-1026.

Schmitt, P., Griswold, M.A., Jakob, P.M., Kotas, M., Gulani, V., Flentje, M., Haase, A., 2004. Inversion recovery TrueFISP: quantification of $\mathrm{T}(1), \mathrm{T}(2)$, and spin density. Magn Reson Med. 51(4), 661-667.

Shih, A.Y., Fernandes, H.B., Choi, F.Y., Kozoriz, M.G., Liu, Y., Li, P., Cowan, C.M., Klegeris, A., 2006. Policing the police: astrocytes modulate microglial activation. J Neurosci. 26(15), 3887-3888.

Sibson, N.R., Lowe, J.P., Blamire, A.M., Martin, M.J., Obrenovitch, T.P., Anthony, D.C., 2008. Acute astrocyte activation in brain detected by MRI: new insights into T(1) hypointensity. J Cereb Blood Flow Metab. 28(3), 621-632.

Snyder, J.S., Kee, N., Wojtowicz, J.M., 2001. Effects of adult neurogenesis on synaptic plasticity in the rat dentate gyrus. J Neurophysiol. 85(6), 2423-2431.

Sorensen, T.L., Tani, M., Jensen, J., Pierce, V., Lucchinetti, C., Folcik, V.A., Qin, S., Rottman, J., Sellebjerg, F., Strieter, R.M., Frederiksen, J.L., Ransohoff, R.M., 1999. Expression of specific chemokines and chemokine receptors in the central nervous system of multiple sclerosis patients. J Clin Invest. 103(6), 807-815.

Stellwagen, D., Malenka, R.C., 2006. Synaptic scaling mediated by glial TNF-alpha. Nature. 440(7087), 1054-1059.

Storer, P.D., Xu, J., Chavis, J., Drew, P.D., 2005. Peroxisome proliferatoractivated receptor-gamma agonists inhibit the activation of microglia and astrocytes: implications for multiple sclerosis. J Neuroimmunol. 161(1-2), 113-122.

Strum, J.C., Shehee, R., Virley, D., Richardson, J., Mattie, M., Selley, P., Ghosh, S., Nock, C., Saunders, A., Roses, A., 2007. Rosiglitazone induces mitochondrial biogenesis in mouse brain. J Alzheimers Dis. 11(1), 45-51.

Tancredi, V., D'Arcangelo, G., Grassi, F., Tarroni, P., Palmieri, G., Santoni, A., Eusebi, F., 1992. Tumor necrosis factor alters synaptic transmission in rat hippocampal slices. Neurosci Lett. 146(2), 176-178.

Vereker, E., O’Donnell, E., Lynch, A., Kelly, A., Nolan, Y., Lynch, M.A., 2001. Evidence that interleukin-1beta and reactive oxygen species production play a pivotal role in stress-induced impairment of LTP in the rat dentate gyrus. Eur J Neurosci. 14(11), 1809-1819.

Yehuda, S., Rabinovitz, S., Carasso, R.L., Mostofsky, D.I., 2002. The role of polyunsaturated fatty acids in restoring the aging neuronal membrane. Neurobiol Aging. 23(5), 843-853.

Yu, A.C., Lau, L.T., 2000. Expression of interleukin-1 alpha, tumor necrosis factor alpha and interleukin- 6 genes in astrocytes under ischemic injury. Neurochem Int. 36(4-5), 369-377.

Zen, K., Utech, M., Liu, Y., Soto, I., Nusrat, A., Parkos, C.A., 2004. Association of BAP31 with CD11b/CD18. Potential role in intracellular trafficking of CD11b/CD18 in neutrophils. J Biol Chem. 279(43), 44924-44930. 